\title{
IMPLIKASI INTERAKSI DESA - KOTA TERHADAP PERKEMBANGAN RUMAH TRADISIONAL MASYARAKAT SUNDA
}

\author{
H a $\mathbf{r}$ t $\mathbf{o}$ n 0 \\ hart20sept@gmail.com \\ SMAN 16 Bandung \\ Jl. Mekarsari No. 81 Kiaracondong Kota Bandung
}

\begin{abstract}
ABSTRAK
Eksistensi suatu bangunan rumah telah mengalami perkembangan pada berbagai aspek akibat adanya interaksi desa-kota yang melanda hampir seluruh masyarakat Sunda di Jawa Barat. Adanya pengklasifikasian bentuk dan tipe rumah mulai dari rumah tradisional, rumah semi modern, dan rumah modern merupakan salah satu bukti perkembangan bentuk rumah berdasarkan kurun waktu dan perkembangan peradaban masyarakat Sunda di Jawa Barat serta perkembangan teknologi. Eksistensi rumahpun diyakini tidak hanya sebagai tempat tinggal dan berlindung manusia dari bahaya luar, namun rumah mempunyai bentuk dan makna yang lebih khusus bagi penghuninya. Artikel ini disusun untuk menguraikan dan mengkaji aspek fisik, nonfisik, serta perkembangan bentuk dan makna rumah tradisional masyarakat Sunda di pedesaan Provinsi Jawa Barat. Aspek fisik dan perkembangan rumah tradisional masyarakat Sunda digali dan dikaji berdasarkan bentuk, material, dan struktur rumah, sedangkan aspek nonfisik yang dikaji berdasarkan makna atau kosmologi rumahnya. Tujuan penulisan adalah untuk dapat mengetahui dan memahami aspek-aspek yang terkandung pada arsitektur bangunan rumah tradisional Sunda baik bentuk maupun makna yang terkandung di dalamnya. Penelurusan dan pengumpulan data-data mengenai rumah tradisional masyarakat Sunda dilakukan melalui observasi dan tinjauan literatur serta dokumen-dokumen yang terkait. Kajian terhadap aspek fisik (bentuk, material, dan struktur) serta perubahan bentuk arsitektur rumah tradisional Sunda di pedesaan, dianalisa berdasarkan disiplin ilmu arsitektur sedangkan pengkajian terhadap aspek nonfisik (makna) rumah tradisional Sunda ditinjau dari aspek fenomologis mengenai kepercayaan dan kosmologi rumah tradisonal. Berdasarkan hasil studi literatur dan observasi, penulis menemukan adanya indikasi terjadinya perubahan aspek fisik dan non fisik rumah tradisional masyarakat Sunda di pedesaan Jawa Barat pada umumnya.
\end{abstract}

Kata kunci: interaksi desa-kota, rumah tradisional masyarakat Sunda.

\section{PENDAHULUAN}

\section{Latar Belakang Masalah}

Wujud dari adanya interaksi kota-desa antara lain adalah terjadinya perubahan sosial dan budaya baik di pedesaan maupun di perkotaan. Perubahan pada aspek sosial dan budaya mencakup berbagai aspek kehidupan yang meliputi kesenian, 
ilmu pengetahuan, teknologi, filsafat, arsitektur dan sebagainya. Ruang lingkup perubahan kebudayaan lebih luas dibandingkan perubahan sosial, namun demikian dalam prakteknya di lapangan kedua jenis perubahan tersebut sangat sulit untuk dipisahkan (Soekanto, 1990). Hal ini dipertegas oleh Soemardjan (1982), bahwa perubahan sosial dan perubahan kebudayaan mempunyai aspek yang sama yaitu keduanya bersangkut paut dengan suatu cara penerimaan caracara baru atau suatu perbaikan dalam cara hidup suatu masyarakat untuk memenuhi kebutuhannya.

Perubahan sosial dan budaya yang terjadi pada masyarakat pedesaan, yakni perubahan dari masyarakat tertutup menjadi masyarakat yang lebih terbuka dan dari nilai-nilai yang bersifat homogen menuju pluralisme nilai dan norma sosial merupakan salah satu dampak dari adanya interaksi desa-kota. Pernyataan tersebut mengandung makna, bahwa perubahan dalam berbagai aspek kehidupan pada masyarakat perkotaan maupun pedesaan merupakan sesuatu yang wajar, mengingat manusia bersifat dinamis dan memiliki kebutuhan yang tidak terbatas. Perubahan terjadi pada berbagai aspek kehidupan, seperti peralatan dan perlengkapan hidup termasuk di dalamnya ruang binaan, mata pencaharian, sistem kemasyarakatan, bahasa, kesenian, sistem pengetahuan, dan religi/keyakinan.

Kebudayaan lokal masyarakat Sunda relatif beranekaragam, antara lain bentuk arsitektur rumah tradisional masyarakat Sunda menjadi suatu kebanggaan sekaligus tantangan untuk mempertahankan serta mewariskannya kepada generasi selanjutnya, tetapi seiring perkembangan zaman, bentuk dan nilai-nilai kearifan lokal arsitektur rumah tradisional tersebut mengalami perubahan kepada sesuatu hal yang dianggap lebih modern dan mungkin dinilai lebih praktis dibandingkan dengan arsitektur rumah tradisional masyarakat Sunda itu sendiri.

Untuk sekedar membuka ruang-ruang indikasi dari pemaknaan atas bangunruang arsitektur masa lalu, saat ini dapat dilakukan dengan menggunakan parameter metodologi budaya yang baku digunakan saat ini. Menurut ilmu sosial dan budaya, suatu hasil kebudayaan dapat dilacak dari dua unsur utama pembentuk kebudayaan, yaitu manusia dan alam. Irisan antara manusia dan alam kemudian membentuk sebuah ruang yang kemudian disebut sebagai ruang binaan, di dalam ruang inilah kemudian budaya-budaya diciptakan untuk mengatasi berbagai masalah manusia dan alam, masalah manusia dengan manusia dan manusia dengan lingkungannya, bahkan suatu budaya diciptakan untuk memecahkan masalah budaya yang muncul sehingga dalam masing-masing lingkaran kosmis tersebut kemudian muncul banyak parameter-parameter yang menyertainya, seiring semakin bertambahnya pengetahuan manusia dalam mengindentifikasi parameter-parameter tersebut. Hal yang menarik kemudian dari metodologi budaya tersebut, adalah dengan ditambahkannya sebuah ruang kosmos yang di dalamnya terdapat ruang alam, manusia dan binaan. Dalam banyak hasil karya, karsa dan cipta manusia-manusia masyarakat sunda masa lalu selalu menambahkan unsur transcendental, yakni unsur ke-Ilahian. Indikasi-indikasi ini dapat dilihat secara nyata dalam beberapa bentuk budaya yang masih tersisa hingga saat ini, salah satunya dari bangun ruang arsitektur di beberapa tempat pada masyarakat Sunda di Jawa Barat. 
Pembagian ruang, konstruksi dan ragam hias dalam bangun ruang arsitektur rumah masyarakat Sunda selain menyatakan fungsi juga menyatakan ajaran-ajaran hidup. Ajaran-ajaran hidup yang berkenaan dengan kehidupan yang selaras dengan alam dan konsepsi ke-Ilahian tersebut terpapar sampai ke unsur-unsur terkecil dalam bangun ruang arsitektur rumah tradisional masyarakat Sunda.

Kini, nilai-nilai tersebut telah mengalami pergeseran seiring dengan perkembangan kebudayaan manusia. Sistem ekonomi, industri, teknologi dan informasi yang melanda dunia secara global perlahan namun pasti mulai menggeser nilai-nilai terdahulu. Ruang kontemplasi, ruang publik kemudian digantikan dengan nilai baru, dari efisiensi sampai argonomis konstruksi, dari kelayakan sampai menjangkau keindahan dan dari ketahanan hingga menyentuh nilai-nilai kearifan lokal yang memuat berbagai informasi mengenai berbagai macam aspek hidup dan kehidupan masyarakat sunda pada masa lalu.

Berdasarkan latar belakang di atas, penulis memiliki beberapa alasan mengapa arsitektur rumah tradisional menarik untuk dibahas, 1) istilah 'rumah (tempat tinggal)', merupakan sesuatu yang sangat dekat dengan keseharian bahkan bisa dikatakan bahwa rumah adalah bagian dari hidup manusia; 2) rumah tradisional sebagai tempat tinggal dilihat dari beberapa aspek telah mengalami perkembangan bentuk sehingga terbangun mitos baru yang maknanya sudah pula mengalami pergeseran.

\section{Tujuan Penulisan}

Adapun tujuan dari penulisan ini, yaitu 1) menjelaskan pengaruh interaksi kota-desa terhadap perkembangan bentuk dan arsitektur rumah tradisional masyarakat Sunda di pedesaan; 2) mengetahui nilai-nilai kearifan lokal apa sajakah yang terdapat pada bentuk arsitektur rumah tradisional masyarakat Sunda di pedesaan; 3) mengetahui faktor-faktor yang menyebabkan perkembangan bentuk dan makna arsitektur rumah tradisional masyarakat Sunda di pedesaan.

\section{HASIL DAN PEMBAHASAN}

\section{Interaksi Desa-Kota}

Desa sebagai suatu region di dalamnya menyangkut unsur-unsur tata ruang dan tata geografi (geographic region) yaitu mencakup gejala-gejala fisis, sosial, ekonomis, kultural, dan politik yang merupakan hasil interaksi antara faktor alami dan faktor manusia. Menurut Bintarto (1989), Desa adalah suatu hasil perpaduan antara kegiatan sekelompok manusia dengan lingkungannya. Hasil perpaduan tersebut adalah wujud atau ketampakan di muka Bumi yang ditimbulkan oleh unsur-unsur fisiografis (fisis), sosial, ekonomi, politik, kultural yang saling berinteraksi antarunsur tersebut, dan juga dalam hubungannya dengan daerahdaerah lain.

Permasalahan yang timbul pada masyarakat desa yang berasal dari permasalahan geografi, sosial, ekonomi, dan budaya di pedesaan, antara lain: 1) sistem kehidupan sosial budaya bersifat tradisional dalam arti masih mempertahankan adat istiadat yang telah melekat sejak dulu dan diwariskan 
secara turun temurun. Sifat ini dapat terlihat dengan jelas pada wilayah-wilayah pedesaan yang masih sangat kuat memegang teguh tradisi leluhur sehingga apabila tidak diwariskan kepada generasi berikutnya ada semacam ketakutan menyalahi aturan dan tidak menghargai leluhur; 2) keterikatan terhadap lahan tinggi, sehingga penduduknya akan mempertahankan lahan yang dimilikinya walaupun sedikit dan akan terus diturunkan melalui sistem bagi waris sehingga lahan yang ada akan terus dimiliki oleh anggota keluarga, kalau pun ada yang keluar dari kepemilikan keluarga itu hanya beberapa pengecualian tentunya dengan berbagai pertimbangan dari seluruh anggota keluarga; 3) lapangan pekerjaan di luar pertanian (non agraris) hampir tidak ada, walaupun ada sifatnya hanya kerja sambilan saja pada waktu aktivitas di lahan pertanian sedang senggang. Jenis pekerjaannya pun tidaklah menetap akan tetapi hanya memilih jenis pekerjaan yang tidak memakan waktu lama sehingga mereka bisa kembali ke pekerjaan di pertanian tepat pada waktunya; dan 4) sistem upah pada sektor pertanian rendah bahkan lebih rendah daripada sistem upah non pertanian. Hal ini dimungkinkan karena tidak ada standar upah pada sektor pertanian yang pasti sehingga sistem upah yang berlaku hanya didasarkan atas kebiasaan yang telah berlaku sebelumnya dan terkadang dilakukan secara suka rela.

Berbagai permasalahan tersebut menimbulkan keterbelakangan kehidupan masyarakat desa. Selain itu, menjadi pemicu terjadinya arus perpindahan penduduk (urbanisasi) yang semakin deras utamanya ke perkotaan.

Secara lebih luas, penggunaan sumber daya pertanahan di pedesaan dapat diuraikan dalam beberapa tahap. Pertama, penggunaan tanah dimulai dengan perladangan berpindah, saat di mana ada sejumlah tanah yang bebas dimiliki. Kedua, penduduk bertambah dan perladangan berpindah tidak mudah lagi dilaksanakan, karena tanah yang bebas digunakan menjadi semakin sedikit sehingga pertanian menetap sudah mulai dikembangkan. Ketiga, mulai berkembangnya pengetahuan dan teknologi, penggarapan tanah diperlakukan secara ekstensif dan intensif. Keempat, daerah-daerah perbukitan dan pesisir diubah menjadi daerah pertanian. Kelima, keseluruhan lingkungan alami akan berubah sebagai akibat dari kegiatan manusia yang dianggap perlu untuk kemajuan manusia.

Pertambahan penduduk yang tinggi telah mengakibatkan kebutuhan pada sumber daya tanah semakin meningkat. Persaingan untuk mendapatkan lahan semakin tinggi, tidak hanya di perkotaan juga hal ini telah nampak di pedesaan. Pada saat keinginan manusia melampui sumber daya atau daya dukung lingkungan dan teknologi yang tersedia dalam periode tertentu, kekurangan sumber daya alam akan muncul.

Kenampakan fisik desa ditandai dengan permukiman yang tidak begitu padat, sarana transportasi langka, penggunaan tanah didominasi oleh lahan pertanian dan perkebunan. Ketampakan sosial-budaya di cirikan dengan ikatan tali kekeluargaan yang begitu erat (gemeinchaft) dengan perilaku gotong royong masyarakat menjadi dominan.

Karakteristik kawasan permukiman penduduk di pedesaan ditandai terutama oleh ketidakteraturan dalam bentuk fisik rumah. Pola permukiman sebuah perkampungan penduduk di perdesaan dapat diidentifikasi dari situs yang berada 
di dekatnya, misalnya sungai. Selain itu, pola permukiman juga bisa mengindikasikan pola mata pencarian penduduknya.

Perumahan di tepi kota dan permukiman dekat dengan kota membentuk pola yang spesifik di wilayah desa-kota. Pada saat pengaruh perumahan kota menjangkau wilayah ini, pola pemukiman cenderung lebih teratur dari pola sebelumnya. Hal ini sangatlah jelas sebagai akibat intervensi para pengembang perumahan di daerah transisi desa-kota.

Kota disebutkan sebagai suatu sistem jaringan kehidupan manusia yang memiliki ciri sosial seperti jumlah penduduk tinggi, strata sosial-ekonomi yang heterogen dengan corak yang materialistis. Berbeda dengan desa, kota memiliki kondisi fisik yang relatif lebih modern, seperti kondisi sarana dan prasarana jaringan transportasi yang kompleks, sektor pelayanan dan industri yang lebih dominan.

Interaksi desa kota dapat diartikan sebagai hubungan timbal balik yang saling mempengaruhi sehingga menghasilkan efek bagi kedua belah pihak. Interaksi kedua tempat ini dipengaruhi oleh munculnya keinginan untuk memenuhi kebutuhan dari kedua tempat bersangkutan. Pola interaksinya tidak hanya terbatas pada faktor ekonomi saja tetapi lebih dari itu pola interaksinya berlangsung dalam seluruh aspek kehidupan. Selain itu, interaksi ini akan memunculkan gerakan penduduk dari kedua tempat sebagai bentuk nyatanya.

Pola pergerakan penduduk dari desa ke kota atau sebaliknya dapat dengan mudah dipelajari melalui pendekatan keilmuan geogafi. Karena pada dasarnya, pergerakan manusia tidak akan pernah keluar dari aspek keruangan (spatial) yang di dalamnya terkandung berbagai unsur baik unsur fisik, sosial, ekonomi dan budaya.

\section{Masyarakat tradisional}

Masyarakat adalah sejumlah manusia yang merupakan satu kesatuan golongan yang berhubungan tetap dan mempunyai kepentingan yang sama yang bertempat tinggal di suatu wilayah. Terdapat dua kelompok masyarakat, yaitu masyarakat paguyuban dan masyarakat petambayan. Masyarakat paguyuban dicirikan dengan terdapatnya hubungan pribadi antara anggota- anggota yang menimbulkan suatu ikatan batin antara mereka. Sedangkan pada masyarakat patembayan dicirikan dengan terdapatnya hubungan pamrih antar anggotanya.

Tradisonal berasal dari bahasa latin yaitu "Traditum" yang memiliki makna Transmitted yaitu pewarisan sesuatu dari sutu generasi ke generasi berikutnya. Ciri-ciri masyarakat tradisional menurut Talcott Parson, antara lain :

1) Afektifitas : yaitu hubungan antar anggota masyarakat didasarkan pada kasih sayang.

2) Orientasi kolektif yaitu lebih mengutamakan kepentingan kelompok/kebersamaan.

3) Partikularisme yaitu segala sesuatu yang ada hubungannya dengan apa yang khusus berlaku untuk suatu daerah tertentu saja, ada hubungannya dengan perasaan subyektif dan rasa kebersamaan.

4) Askripsi yaitu segala sesuatu yang dimiliki diperoleh dari pewarisan generasi sebelumnya. 
5) Diffuseness ( kekaburan ) yaitu dalam mengungkapkan sesuatu dengan tidak berterus-terang.

Selain itu ciri lainnya dari masyarakat tradisional dapat ditambahkan antara lain sebagai berikut :

1) Masyarakat yang terikat kuat dengan tradisi.

2) Masyarakatnya homogen ( hampir dalam segala aspek).

3) Sifat pelapisan sosialnya tertutup

4) Mobilitas relative sulit terjadi.

5) Perubahan terjadi secara lambat.

6) Masyarakatnya cenderung tertutup terhadap perubahan.

\section{Implikasi Interaksi Desa-Kota terhadap Perkembangan Bentuk dan Makna Rumah Tradisional Masyarakat Sunda}

Dalam tulisan Edi S. Ekajati (1995), R.W.van Bemmelen menyatakan, bahwa istilah "Sunda" awalnya digunakan untuk menamai dataran bagian barat laut wilayah Hindia Timur, sedangkan dataran bagian tenggara dinamai Sahul. Dalam bahasa Sansekerta kata "Suddha" memiliki arti "dari jauh tampak putih bercahaya", pada awalnya digunakan untuk menamai Gunung Sunda yang dalam perkembangan selanjutnya nama tersebut digunakan untuk menamai wilayah tempat gunung itu berada.

Menurut Pelamonia (2010), Suku Sunda merupakan salah satu suku yang menempati wilayah Pulau Jawa bagian barat. Daerah yang didiami oleh suku Sunda disebut Tatar Sunda atau Tanah Pasundan. Suku Sunda merupakan salah satu suku yang sebagian besar penduduknya mendiami Tatar Pasundan dan bertetangga dengan beberapa suku lainnya sepeti Banten, Cirebon dan suku Badui. Keberadaannya di Jawa Barat hingga saat ini masih menjadi sebuah misteri bagi para peneliti. Hal ini disebabkan karena tidak adanya cerita-cerita yang dapat dijadikan sumber untuk mengungkap asal usul suku ini.

Pola hidup masyarakat Sunda Kuno adalah berladang. Komunitas peladang ini hidupnya cenderung berpindah-pindah (nomaden). Masa tinggal mereka di suatu tempat disesuaikan dengan masa berladang yang relatif singkat, yang tak memerlukan teknik irigasi. Maka itu, mereka tak merasa perlu untuk membangun tempat tinggal untuk didiami selama-lamanya. Karenanya, hingga kini jarang sekali ditemukan bangunan-bangunan kuno peninggalan masa Sunda-Galuh (apalagi masa Salakanagara dan Tarumanagara) seperti biara atau candi. Mungkin satu-satunya candi yang bisa dibanggakan orang Sunda adalah Candi Cangkuang di Garut. Jangan heran pula, mengapa istana di Pakuan, yang dalam cerita-cerita pantun dan babad dilukiskan begitu megah, tak meninggalkan jejak-jejaknya. Tak seperti candi-candi di Jawa Tengah, Jawa Timur, dan Sumatera yang terbuat dari batu bata dan batu-batu kali yang diukir dengan ornamen-ornamen yang sangat detail. Istana Pakuan hanya terbuat dari tanah liat dan batu-batu yang dijejerkan dan tidak ada relief-relief yang rumit di dalam istana.

Budaya bersawah memang kemudian dikenal pada masa Pajajaran. Namun, area persawahan pada masa itu pun hanya berada di wilayah yang berdekatan dengan kota Pakuan. Sedangkan masyarakat Sunda pada umumnya, di luar Pakuan, tetap bekerja sebagai peladang. Para petani menggarap sawah mereka 
untuk keperluan orang-orang di kota Pakuan semacam bangsawan, kawula istana, dan keluarga raja. Hasil sawah dan juga ladang lalu diperjualbelikan di pasar yang terletak di alun-alun depan gerbang Pakuan. Sistem persawahan baru dikenal luas oleh masyarakat Sunda ketika Singaperbangsa (keturunan Adipati Kertabumi yang diangkat Sultan Agung menjadi wedana) bersama Ki Wirasaba dari Banyumas menjaga perbatasan wilayah kekuasaan Mataram di sebelah barat Priangan.

\section{Perkembangan Bentuk Arsitektur dan Makna Rumah Tradisional Masyarakat Sunda}

Dari segi arsitektur kita meyakini bahwa suatu bentuk pada umumnya tercipta untuk memenuhi tujuan tertentu. Setiap bentuk arsitektur rumah tradisional cenderung dilatarbelakangi oleh sistem kognisi yang ditentukan oleh kualitas hubungan antara manusia dengan lingkungan dan manusia dengan sang pencipta. Tatanan serta bentuk arsitektur yang masih kuat berlandas pada tradisi merupakan ekspresi dari makna, nilai, dan kepercayaan yang dianut suatu komunitas dalam kurun waktu tertentu.

Pemahaman mendalam mengenai budaya masyarakat setempat merupakan hal yang penting, karena karya arsitektur tidak akan pernah lepas dari konteks budaya dimana arsitektur itu berada. Jika kebudayaan masyarakat berubah, maka arsitektur sendiri cenderung akan mengalami perubahan. Sejarah membuktikan bahwa budaya dan arsitektur cenderung membuka diri terhadap pengaruh yang datang dari luar. Budaya dan arsitektur dalam kenyataannya tidak pernah statis, tetapi selalu berubah sepanjang waktu dan menyesuaikan diri dengan kondisi kehidupan masyarakat.

Kebudayaan adalah hasil kreativitas manusia untuk menghadapi tantangan hidupnya atau merupakan hasil akumulasi dari seluruh aspek kehidupan masyarakat pendukungnya dalam memenuhi kebutuhannya. Karena itu, kebudayaan merupakan satu kesatuan yang tak dapat dipisahkan dari kehidupan nyata. Kebudayaan dan masyarakat merupakan satu kesatuan yang tidak dapat dipisahkan satu dengan lainnya. Kebudayaan tidak mungkin timbul tanpa adanya masyarakat dan eksistensi masyarakat itu sendiri dimungkinkan oleh adanya kebudayaan (Harsojo, 1982:144). Kesinambungan hidup, masyarakat dari masa ke masa terjaga dengan adanya kebudayaan, melalui pewarisan sejumlah tradisi yang berkaitan dengan berbagai aspek kehidupan masyarakat dan merupakan akumulasi kebiasaan-kebiasaan hidup yang telah diakui keberadaannya oleh masyarakat tersebut. Yudistira Garna dalam makalahnya mengenai perubahan sosial di Indonesia menjelaskan bahwa tradisi yang ada di dalam setiap masyarakat adalah tatanan sosial yang berwujud mapan, baik mapan sebagai bentuk hubungan antara unsur-unsur kehidupan maupun sebagai bentuk aturan sosial yang memberi pedoman tingkah laku dan tindakan anggota suatu masyarakat. Tak mengherankan kalau tradisi merupakan warisan sosial budaya yang selalu ingin dipertahankan oleh warga masyarakat pendukungnya sebagai identitas penting kehidupan mereka. Selanjutnya dikatakan bahwa dalam suatu kebudayaan selalu ada suatu kebebasan tertentu pada para individu. Kebebasan individu tersebut memperkenalkan variasi dalam cara-cara berlaku dan variasi itu pada akhirnya 
dapat menjadi milik bersama. Dengan demikian, di kemudian hari ia akan menjadi bagian dari kebudayaan atau mungkin beberapa aspek dari lingkungannya akan mempengaruhi perubahan yang memerlukan proses adaptasi.

Gelombang modernisasi melalui interaksi desa kota merupakan fenomena sosial dan budaya yang menyertai dinamika hidup masyarakat. Modernisasi yang dalam hal ini diartikan sebagai usaha untuk hidup sesuai dengan jaman dan konstelasi dunia sekarang (Koentjaraningrat, 1993 : 140-141), semakin dipertajam dengan berlangsungnya era globalisasi seperti sekarang ini, yang merebak ke dalam berbagai aspek kehidupan masyarakat pedesaan. Modernisasi sebagai konsep dalam kepustakaan ilmu-ilmu sosial dapat diartikan sebagai suatu sikap pikiran yang mempunyai kecenderungan untuk mendahulukan sesuatu yang baru daripada yang bersifat tradisi dan satu pikiran yang hendak menyesuaikan soalsoal yang sudah menetap dan menjadi adat kepada kebutuhan-kebutuhan yang baru (Harsojo, 1982 : 265). Sementara itu globalisasi / era kejagatan seringkali dimuati unsur-unsur budaya asing yang keberadaannya perlu dikaji lebih jauh kesesuaiannya dengan kebudayaan masyarakat setempat.

Menghadapi fenomena-fenomena sosial tersebut, tatanan hidup masyarakat pedesaan setempat yang berupa sejumlah tradisi penting dan menjadi pedoman hidup suatu masyarakat eksistensinya dipertaruhkan. Dalam hal ini, bahwa pengaruh luar cenderung merupakan suatu kekuatan mutlak yang tidak mudah ditolak oleh masyarakat setempat, namun tak bisa dipungkiri pula kalau hingga kini pun masih tersisa sejumlah kelompok masyarakat yang tak perduli dengan hal yang berbau modern. Kelompok masyarakat yang menggambarkan kondisi tersebut adalah masyarakat adat yang hidup dalam sebuah lingkungan adat yang sangat dipatuhinya. Mereka hidup dalam kelompok yang memisahkan diri secara formal dari tatanan budaya pada umumnya. Berikut ini adalah kelompok masyarakat di Jawa Barat dan Banten yang relatif masih memegang teguh nilainilai dan pranata sosial yang dipatuhinya :

1) Kelompok Masyarakat adat Kampung Kuta di Cisaga Kabupaten Ciamis

2) Kelompok Masyarakat adat Kampung Naga di Salawu Kabupaten Tasikmalaya

3) Kelompok Masyarakat adat Kampung Pulo Panjang di Leles / Cangkuang Kab. Garut

4) Kelompok Masyarakat adat Kampung Dukuh di Cikelet Kabupaten Garut

5) Kelompok Masyarakat adat Kampung Mahmud di Margahayu Kabupaten Bandung

6) Kelompok Masyarakat adat Kampung Ciptagelar, Sirnaresmi, Ciptarasa, Bayah, Citorek, Cicemet, Sirnarasa, di Palabuhanratu Kabupaten Sukabumi

7) Kelompok Masyarakat adat Kampung Urug di Kiarapandak - Cigudeg Kabupaten Bogor

8) Kelompok Masyarakat adat Kampung Baduy / Kanekes di Leuwidamar Kabupaten Lebak.

Kampung-kampung adat tersebut di atas merupakan perkampungan yang dihuni oleh sekelompok masyarakat yang sangat kuat dalam memegang adat istiadatnya. Hal itu akan terlihat jelas perbedaannya bila dibandingkan dengan masyarakat lain di luar kampung tersebut pada umumnya. Masyarakat Kampung 
adat, hidup pada suatu tatanan yang dikondisikan dalam suatu kesahajaan dan lingkungan kearifan tradisional yang lekat. Dengan demikian, Kampung adat tersebut di atas adalah potret masyarakat pedesaan di Jawa barat yang mampu melepaskan keterikatan akan perkembangan modernisasi juga pengaruh globalisasi informasi yang tengah melanda seluruh pelosok dunia dengan ciri fisik seperti bentuk rumah yang masih mempergunakan arsitektur tradisional dan dengan segala bentuk pantangan yang harus dipatuhinya.

Kesahajaan hidup dan lingkungan kearifan tradisional adalah ciri mandiri dalam segala tingkah lakunya, sehingga dinamika hidupnya selalu diwarnai oleh keterikatan dirinya akan pedoman hidup yang telah mempranata dan merupakan harta kekayaan yang tak ternilai harganya. Masyarakat Kampung adat dengan kearifannya mampu bertahan hidup 'survive' dan tidak melepaskan kekhasannya yang menjadi ciri mandiri jati dirinya.

Menurut Pelamonia (2010), secara umum rumah tradisional masyarakat Sunda di pedesaan merupakan rumah panggung sama seperti rumah-rumah tradisional lainnya yang ada di Indonesia. Bentuk rumah panggung bertujuan untuk menghindari masalah-masalah dari lingkungan yang bisa mengancam penghuninya. Berdasarkan bentuk atapnya, rumah tradisional Sunda terbagi atas beberapa ciri yang berbeda satu dengan lainnya, seperti terlihat pada gambar 1 .

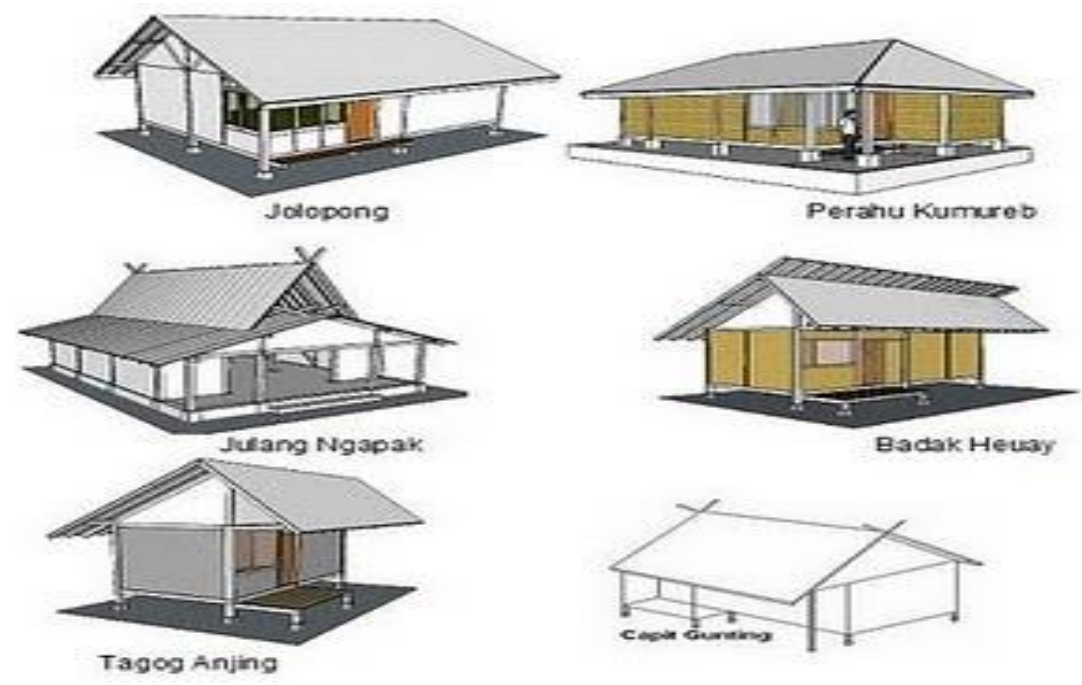

Gambar 1. Jenis dan Bentuk Rumah Tradisional Sunda

Bentuk pondasi rumah tradisional Sunda mirip dengan pondasi umpak yang dipakai untuk rumah-rumah tradisional jaman sekarang. Perbedaannya adalah bentuk pondasi yang unik yaitu kolom bangunan hanya diletakan di atas sebuah batu datar yang sudah terbentuk di alam. Tujuan pembuatan pondasi seperti ini adalah untuk menghindari keretakan atau pada kolom bangunan pada saat terjadi gempa, sedangkan bentuk lantai panggung bertujuan untuk memungkinkan sirkulasi udara dari bawah lantai dapat berjalan baik sehingga kelembaban pada lantai bangunan dapat dihindari. Lantai rumah terbuat dari pelupuh (bambu yang sudah dibelah). Bahan ini dimaksudkan agar udara yang melewati kolong rumah 
dapat masuk ke ruang-ruang sehingga dapat menjaga tingkat kelembaban di dalam rumah.

Dinding bangunan terbuat dari anyaman bambu yang dapat dilewati udara, jendela yang selalu terbuka dan hanya ditutupi kisi-kisi bambu maka udara dapat bebas masuk dalam ruangan, sehingga suhu di dalam ruangan tidak panas. Dinding yang ringan terbuat dari anyaman bambu dapat menyerap dan mencegah terjadinya panas akibat radiasi matahari sore hari. Selain itu material dinding yang terbuat dari anyaman bambu memungkinkan udara untuk masuk ke dalam rumah. Ada juga pintu dan jendela yang mempunyai daun pintu dan daun jendela tunggal. Materialnya terbuat dari kisi-kisi bambu yang dapat ditembus oleh udara. Hal ini membuat suasana di dalam rumah tetap nyaman.

Plafon selain sebagai penghias langit-langit rumah juga berfungsi sebagai tempat untuk menyimpan barang. Kerangka plafon terbuat dari susunan bambu bulat, dan di atasnya diletakan pelupuh sebagai bahan penutup plafon. Sedangkan atap sebagai mahkota dari sebuah bangunan mempunyai fungsi untuk melindungi penghuni yang berada di dalamnya. Atap rumah terbuat dari ijuk agar dapat menyerap panas dengan baik sehingga tidak menimbulkan suasana gerah di dalam rumah. Tritisan pada sisi depan rumah mempunyai panjang 2 meter. Hal ini membuat dinding bangunan tidak langsung terkena cahaya matahari sehingga dinding sebagai penyekat tidak panas dan ruang di dalamnya tetap dingin. Selain itu, ada juga sisi yang disebut sebagai bidang atap terbuat dari anyaman bambu dan berfungsi sebagai ventilasi atap.

Rumah-rumah yang umum terdapat di desa-desa di Jawa Barat pada tempo dulu atapnya berbentuk limasan dengan dinding bambu (gedhek). Atapnya terbuat dari anyaman daun kelapa, sirap ataupun alang-alang, dindingnya terbuat dari bilik ,yakni sejenis anyaman dari bambu. berdasarkan suasananya, deretan rumah tersebut kelihatan tenang dan menenteramkan serta menyatu dalam keseimbangan alam desa. Selain itu, rumah tradisional Sunda mempunyai tata letak yang sangat rapi hal ini merupakan pengaruh dari kepercayaan masyarakat bahwa rumah tidak boleh menghadap ke bumi (rumah) adat, dengan demikian orientasi dari rumah tradisional sunda biasanya mengarah ke timur dan barat.

Hal demikian berbeda jauh keadaannya dengan kondisi sekarang, pedesaan masyarakat Sunda sudah penuh dengan bangunan semi modern ataupun modern beratap genting, internit, fiber, ataupun bahan hasil pabrikan lainnya yang relatif tidak ramah lingkungan. Dewasa ini bentuk-bentuk rumah tradisional masyarakat Sunda di pedesaan sudah banyak mengalami perkembangan, baik bentuk arsitektur maupun bahan yang digunakan, dalam arti lain bahwa arsitektur rumah masyarakat Sunda yang asli sudah mulai ditinggalkan terutama di daerah-daerah pedesaan yang bukan kampung adat. Rumah di pedesaan mayarakat Sunda Jawa Barat mungkin akan menjadi tinggal kenangan belaka digantikan dengan bentukbentuk rumah modern yang dianggap lebih praktis dan prestisius, sehingga makna dan nilai-nilai kearifan lokal didalamnya mengalami pergeseran .

\section{Perkembangan Makna dan Nilai-Nilai Kearifan Lokal yang Terdapat pada Bentuk Arsitektur Rumah Tradisional Masyarakat Sunda}


Berdasarkan hasil kajian di beberapa pedesaan masyarakat Sunda, maka nilainilai kearifan lokal yang terdapat pada rumah tradisional masyarakat Sunda, antara lain :

a. Bahan bangunan yang digunakan umumnya terdiri atas bahan alami yang ramah lingkungan, seperti kayu, bambu, ijuk, daun kepala, sirap, batu maupun tanah yang banyak terdapat di lingkungan sekitar, biasanya dibangun berbentuk panggung dengan tinggi antara 40-60 m dari permukaan tanah. Hal ini dimaksudkan untuk adanya sirkulasi udara dan juga untuk menghindari ancaman binatang buas.

b. Mempunyai konstruksi tahan gempa

Rumah tradisional masyarakat Sunda fleksibel dan stabil terhadap gempa. Hal ini disebabkan oleh beberapa ciri rumah tradisional sunda, antara lain :

1) Struktur rumah tradisional masyarakat Sunda tidak sekaku struktur rumah beton. Karena rangka utamanya (core frame) terdiri dari batu (umpak), kolom utama dan kolom-kolom penguat. Kolom utama umumnya berdiri tegak dan diantaranya terdapat kolom-kolom penguat yang bersilangan, menyerupai huruf $\mathrm{x}$ miring. Kolom-kolom inilah yang berfungsi untuk menahan beban lateral yang bergerak horizontal ketika terjadi gempa.

2) Struktur rumah tradisional masyarakat Sunda yang berbahan kayu menghasilkan kemampuan meredam getaran/guncangan lebih efektif, lebih fleksibel dan juga stabil.

3) Kolom/kolong rumah tradisional masyarakat Sunda memiliki tumpuan sendi dan rol atau ikatan antara balok kayu yang saling mengunci tanpa dipaku. Kolom-kolom tegak dihubungkan dengan kolom-kolom penguat atau balok-balok penyangga melalui sambungan sistem pasak. Teknik pasak pada sambungan kayu membuat balok-balok kayu tidak patah ketika terjadi gempa, karena balok-balok penyangga ini yang dapat berputar bebas seperti engsel pada jarak tertentu.

c. Dalam masyarakat Sunda arsitektur rumah merupakan cerminan dari kegiatan yang dilakukan sehari-hari dalam masyarakat dalam arti masyarakat Sunda tradisional selalu menjunjung tinggi nilai-nilai hubungan antara manusia dengan Tuhan, manusia dengan alam, manusia dengan masyarakat dan manusia dengan pribadinya.

Seiring dengan terjadinya perkembangan bentuk arsitektur rumah tradisional masyarakat Sunda yang telah mengalami perubahan dari yang bersifat tradisional menjadi bentuk-bentuk yang bersifat semi modern dan modern yang disebabkan adanya implikasi dari interaksi desa-kota, maka makna berupa nilai-nilai kearifan lokal yang terkandung dalam arsitektur rumah tradisional masyarakat Sunda itupun ikut mengalami pergeseran.

Faktor-Faktor yang Menyebabkan Terjadinya Perkembangan Bentuk dan Makna Arsitektur Rumah Tradisional Masyarakat Sunda

Perkembangan dan perubahan arsitektur rumah masyarakat Sunda di pedesaan menjadi arsitektur semi modern dan modern disebabkan oleh faktor-faktor:

1) Sikap masyarakat. Sikap masyarakat Sunda di pedesaan cenderung telah mengalami perubahan dari masyarakat tertutup menjadi masyarakat yang lebih 
terbuka dan dari kondisi masyarakat yang menjunjung nilai-nilai yang bersifat homogen menuju pluralisme nilai dan norma sosial.

2) Mobilitas horizontal. Mobilitas horizontal tinggi karena masyarakat pedesaan kini lebih memiliki kemampuan untuk bergerak dalam arti lain, arus perpindahan penduduk pedesaan yang semakin deras ke berbagai wilayah termasuk di antaranya ke perkotaan (urbanisasi) sehingga memicu perubahan di berbagai aspek kehidupan sekembalinya mereka ke pedesaan tempat asalnya, termasuk perubahan gaya arsitektur rumah tradisional menjadi arsitektur rumah semi modern ataupun modern.

3) Kurangnya kesadaran masyarakat. Kesadaran masyarakat sunda di pedesaan untuk menjaga budaya lokal berupa arsitektur rumah tradisional sekarang ini sudah terbilang minim. Masyarakat lebih memilih arsitektur rumah modern yang dianggap lebih prestisius, lebih praktis dan lebih sesuai dengan perkembangan zaman.

4) Kurangnya pembelajaran budaya.Pembelajaran tentang budaya yang mengandung nilai-nilai kearifan lokal tentunya harus ditanamkan sejak dini, namun sekarang ini banyak masyarakat yang sudah tidak menganggap penting mempelajari budaya lokal. Padahal melalui pembelajaran budaya, kita dapat mengetahui pentingnya membangun budaya bangsa dan bagaimana cara mengadaptasi budaya lokal di tengah perkembangan zaman.

\section{SIMPULAN}

Sebagai simpulan tulisan ini, bahwa perubahan selalu terjadi di belahan dunia manapun, tidak terkecuali pada masyarakat Sunda di pedesaan. Proses yang terjadi ini merupakan suatu yang alamiah, sesuatu yang tidak bisa dihindari oleh manusia. perubahan yang bersifat dinamis dan arus globalisasi yang tinggi menyebabkan sebagian masyarakat sunda kurang memiliki kesadaran akan pentingnya peranan budaya lokal dalam memperkokoh ketahanan budaya bangsa. Padahal sesungguhnya budaya lokal yang kita miliki ini dapat menjadikan kita lebih bernilai dibandingkan bangsa lain. Untuk itu, seharusnya kita bisa lebih tanggap dan peduli lagi terhadap semua kebudayaan yang ada di Indonesia khususnya budaya lokal masyarakat sunda ini. Selain itu kita harus memahami arti kebudayaan serta menjadikan keanekaragaman budaya yang ada di Indonesia sebagai sumber kekuatan untuk ketahanan budaya bangsa.

Khasanah arsitektur rumah tradisional di Indonesia sangat beragam setara dengan pluralitas suku-suku bangsa di wilayah Nusantara termasuk suku sunda di Jawa Barat, dimana keragaman ini dijalin oleh suatu kearifan tradisional (indigenous knowledge) yang salah satunya adalah dalam hal beradaptasi terhadap ancaman bencana alam, yaitu : ketahanannya terhadap gempa bumi dan ancaman dari bahaya lingkungan sekitar terutama binatang buas.

Bentuk dan gaya rumah adat masyarakat Sunda sudah sangat jarang ditemui, khususnya di daerah perkotaan dan daerah transisi desa-kota yang sudah berganti dengan nama dan gaya dari "barat". Tentunya hal ini bukan tanpa alasan, 
kemajuan zaman dan adanya interaksi desa-kota, membuat banyak bentuk rumah masyarakat sunda di pedesaan lebih bergaya modern.

Beruntung keberadaan kampung adat maupun kampung budaya di Jawa Barat sangat menolong eksistensi bentuk dan gaya rumah adat masyarakat Sunda di beberapa daerah yang masih mempertahankan bentuk aslinya. Masyarakat Sunda tradisional selalu menjunjung tinggi nilai-nilai hubungan antara manusia dengan Tuhan, manusia dengan alam, manusia dengan masyarakat dan manusia dengan pribadinya.

\section{DAFTAR PUSTAKA}

Adimihardja, Kusnaka. (1984). Tipe Rumah Khas Sunda Jawa Barat. Bandung: Kanwil Pariwisata Jawa Barat.

Ardy Arsyad. (2009). Rumah Tradisional Tahan Gempa. [Online]. Tersedia: http://web.civileng-unhas. (12 Nopember 2010).

Bintarto, R.(1989). Interaksi Desa Kota dan permasalahannya. Jakarta : Ghalia Indonesia.

Ekadjati, Edi. S. (1995). Kebudayaan Sunda: Suatu pendekatan Sejarah. Jakarta : Pustaka Jaya.

Evawani Ellisa. (2008). Rumah-rumah Oval Tahan Gempa di Nias Utara. [Online]. Tersedia: $\quad \underline{\text { http://www.goethe.de/ins }}$ /id/lp/prj/art/arc/pla/ess/id740620.htm. (12 Nopember 2010).

Harsojo. (1982). Pengantar antropologi. Jakarta : Binacipta.

Koentjaraningrat. (1990). Beberapa Pokok Antropologi Sosial. Jakarta: Dian Rakyat.

Koentjaraningrat. (1993). Masalah Kesukubangsaan dan Integrasi Nasional. Jakarta : Gramedia Pustaka Utama.

Marbun, B.N.(1988). Proses Pembangunan Pedesaan. Jakarta : Erlangga.

Mutakin, Awan. (2008). Individu, Masyarakat dan Perubahan Sosial. Bandung : FPIPS UPI

Pelamonia, Frans. (2010). Perkembangan Arsitektur Pada Rumah Tradisional Suku Sunda - Jawa Barat. [Online]. Tersedia: http://fpelamonia.blogspot.com/2010_01_01_archive. html. (12 Nopember 2010).

Sumarjo, J. (2006). Estetika Paradoks. Bandung : Sunan Ambu Press.

Soekanto,Soerjono.(1990) Sosiologi Suatu Pengantar. Jakarta: Rajawali.

Soemardjan, Selo. (1982). Setangkai Bunga Sosiologi. Jakarta: UI Press. 